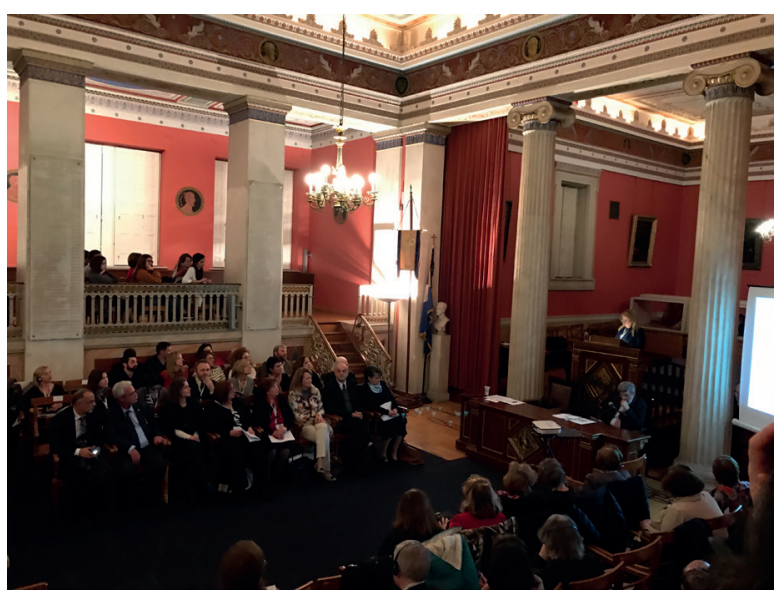

E. Стерьёпулу, Т. Борисова (Афинь, Гречия)

Международная научная конференция «Русская литература и ее взаимосвязь с другими национальными литературами Европы» в Афинском национальном университете им. И. Каподистрии

H. Stergiopoulou, T. Borisova (Athens, Greece)

\title{
International Research Conference "Russian Literature and Its Relationship with Other National Literature in Europe" in the National and Kapodistrian University of Athens
}

В Афинах 22-23 февраля 2018 г. состоялась международная научная конференция «Русская литература и ее взаимосвязь с другими национальными литературами Европы», организованная факультетом русской филологии и славяноведения Афинского национального университета им. И. Каподистрии, возглавляемым профессором Еленой Стерьёпулу. Конференция прошла под эгидой президента Греции Прокописа Павлопулоса. Участниками данного научного форума стали более пятидесяти ученых-филологов из двенадцати стран: Армении, Бельгии, Болгарии, Великобритании, Греции, Италии, Литвы, России, Сербии, США, Украины и Франции. Особенно широко были представлены на конференции Греция и Россия специалистами из ведущих вузов Афин (Афинский национальный университет им. И. Каподистрии, Греческий открытый университет, Военное училище Эвэлпидов), других городов Греции (Фракийский университет им. Демокрита, Университет им. Аристотеля в Салониках) и разных городов России (Московский государственный университет, Московский педагогический государственный университет, Санкт-Петербургский государственный университет, Новосибирский национальный исследовательский государственный университет, Южный федеральный университет). Самая крупная делегация представляла филологический факультет МГУ. В ее число входили не только преподаватели (заведующая кафедрой славянской филологии профессор Наталья Евгеньевна Ананьева, профессор Алла Геннадьевна Шешкен и доцент Ольга Михайловна Савельева), но и аспиранты и студенты (Анетта Багаева и Ростислав Ярцев). На открытии и заседаниях конференции присутствовали атташе по культуре Посольства Болгарии в Греции Пантелей Стасов, представители посольств Польши, Сербии и Украины.

Год проведения конференции совпал с двумя юбилейными датами: 180-летием со дня основания Афинского национального университета и первым десятилет- 
ним юбилеем молодого факультета русской филологии и славяноведения. В приветственных словах, прозвучавших на торжественном открытии конференции, состоявшемся 22 февраля в главном зале Центрального здания университета, проректор Наполеон Маравегиас и директор Института философии Афинского университета Елени Карамолегу отметили ведущую роль факультета в укреплении научных и культурных связей между Грецией и Россией, в распространении русского языка и культуры в Греции. В своем выступлении декан факультета Елени Стерьёпулу кратко рассказала об основных достижениях факультета за прошедшие десять лет, подчеркнув, что они пришлись на самый трудный для экономики страны и высшего образования период. Несмотря на это факультет может с гордостью констатировать, что ему удалось не только укрепить свои позиции в сфере греческого университетского образования, но и добиться международного признания. Об этом свидетельствует, в частности, успешное сотрудничество факультета с ведущими вузами России, Болгарии, Польши, Украины, Белоруссии, Словакии, Грузии, Германии, Армении и Азербайджана, а также с Фондом Александра Солженицина и Благотворительным фондом Ивана Саввидиса, участие в международных программах Erasmus Mundus, Hermes, проведение международных научных и студенческих конференций и т. д.

На состоявшемся после открытия конференции пленарном заседании прозвучали три выступления филологов-неоэллинистов, профессоров Элени Политу-Мармарину, Эразмии Луизы Ставропулу и Ставрулы Цупру, посвященные влиянию трех великих русских писателей XIX в.: Л. Толстого, Ф. Достоевского и А. Чехова - на греческую литературу конца XIX - начала XX в., в частности на творчество Александроса Пападиамандиса, Янниса Бератиса и Тасоса Афанасиадиса. Первый день работы конференции завершился мини-спектаклем студенческого театра. Вниманию участников конференции была представлена одноактная пьеса А. Блока «Балаганчик» в греческом переводе преподавателя факультета Афанасиоса Нациса.

23 февраля работа конференции была продолжена в двух секциях, посвященных влиянию русской литературы на другие европейские литературы и европейскому влиянию на русскую литературу соответственно. На четырех заседаниях, прошедших в каждой из секций, было заслушано 46 выступлений, в совокупности охватывающих всю многовековую историю русской литературы от ее истоков до современной эпохи и выявляющих различные аспекты ее взаимовлияний с другими европейскими литературами: греческой, немецкой, французской, итальянской, английской, польской, болгарской, сербской и др. Особое внимание было уделено роли писателей-гигантов русской литературы - Ф. Достоевского и А. Чехова - в формировании новой европейской ментальности, а также западно-европейскому культурному контексту в произведениях писателей Серебряного века. Подробно было освещено влияние античной греческой и византийской культуры на русскую литературную традицию, во многих выступлениях были подчеркнуты и проанализированы глубокие духовные и культурные узы, связывающие наши народы. Интерес вызвали и доклады, посвященные греческо-русским культурным связям в XIX-XX вв. (о влиянии Ф. Достоевского на творчество Пападиамандиса, о путешествиях Н. Казандзакиса в послереволюционную Россию и русских художников Л. Бакста и В. Серова в Грецию, о Греции в творчестве Марины Цветаевой). В ряде выступлений говорилось о взаимовлияниях русской литературы и литератур других славянских народов (о влиянии русской поэзии на южнославянскую систему стихосложения, о польском интертексте в русской литературе XIX- 
XX вв. и др.), было прослежено, как изменялось на протяжении XVIII-XXI вв. отношение к русской литературе, а также образ России в сознании и культуре других славянских народов. Особо хотелось бы отметить доклады, посвященные переводам русских писателей на другие европейские языки, об их творческой интерпретации в культуре других народов (в частности, о постановке пьес А. Чехова выдающимся греческим режиссером Яннисом Хувардасом). Наконец, о влиянии русской литературы за границами европейского континента говорилось в докладе, посвященном воздействию творчества Владимира Маяковского на турецкого поэта Назыма Хикмета.

Подводя итоги конференции, декан факультета русской филологии и славистики Елена Стергьёпулу подчеркнула особую роль литературы для понимания национального самосознания народа и для успешного межкультурного диалога. Не подлежит сомнению, что данная конференция, на которой прозвучало много интересных и оригинальных выступлений и прошли плодотворные дискуссии и обмены мнениями, знаменует новый этап в развитии сопоставительного литературоведения и будет способствовать дальнейшему изучению связей русской литературы с другими литературами Европы. С радостью и гордостью можно констатировать огромный интерес к русской литературе в греческом обществе, о чем свидетельствовали постоянно заполненные залы конференции. Особенно отрадно для всех участников было активное участие в работе конференции студентов факультета русской филологии и славяноведения, их помощь в организации мероприятия, присутствие на заседаниях и заинтересованные вопросы. Оргкомитет и участники конференции выразили надежду, что данное событие положит начало периодически проводимым конференциям по сравнительному литературоведению и будет способствовать укреплению научных контактов между специалистами-филологами европейских стран.

$\begin{array}{rr}\text { Елена Стерьёпулу, } & \text { Cведения об авторах } \\ \text { доктор филол. наук, профессор } & \text { Helen Stergiopoulou, } \\ \text { факультет русской филологии и славяноведения } & \text { Faculty of Russian Philology and Slavic Studies } \\ \text { Афинский национальный университет } & \text { National and Kapodistrian University of Athens } \\ \text { им. И. Каподистрии } & \text { Doctor of Philology, Professor } \\ \text { Татьяна Борисова, } & \text { Tatiana Borisova, } \\ \text { канд. филол. наук } & \text { PhD } \\ \text { научный сотрудник } & \text { Research Associate } \\ \text { факультет русской филологии и славяноведения } & \text { Faculty of Russian Philology and Slavic Studies } \\ \text { Афинский национальный университет } & \text { National and Kapodistrian University of Athens } \\ \text { им. И. Каподистрии } & \text { tatianaborissova@gmail.com }\end{array}$

